DOI: https://doi.org/10.47405/mjssh.v6i2.670

\begin{tabular}{|c|c|}
\hline & Malaysian Journal of Social Sciences and Humanities (MJSSH) \\
\hline Malaysian Journal of & Volume 6, Issue 2, February 2021 \\
\hline $\begin{array}{l}\text { Humanities } \\
\text { (mJ-sst) }\end{array}$ & e-ISSN : 2504-8562 \\
\hline & $\begin{array}{l}\text { Journal home page: } \\
\text { www.msocialsciences.com }\end{array}$ \\
\hline
\end{tabular}

\title{
Tahap Kepuasan Pelajar Universiti Sains Malaysia (USM) Terhadap Perkhidmatan Kemudahan Kesihatan dalam Kampus Induk
}

\author{
Sofia Haminah Mohd Som1', Sharifah Rohayah Sheikh Dawood 1 \\ 1Bahagian Geografi, Pusat Pengajian Ilmu Kemanusiaan, Universiti Sains Malaysia (USM) \\ Correspondence: Sharifah Rohayah Sheikh Dawood (sdawood@usm.my)
}

\begin{abstract}
Abstrak
Setiap universiti sememangnya menawarkan perkhidmatan kemudahan kesihatan untuk dimanfaatkan oleh setiap warganya di dalam kampus terutama pelajar. Perkhidmatan kemudahan kesihatan yang baik merupakan perkara utama yang perlu dititikberatkan oleh pihak universiti bagi memastikan kelestarian kesihatan pelajar terjamin. Kepuasan pelajar merupakan perkara yang penting untuk menilai kualiti perkhidmatan kemudahan kesihatan yang disediakan oleh universiti. Oleh itu, makalah ini bertujuan untuk mengkaji tahap kepuasan pelajar USM terhadap perkhidmatan kemudahan kesihatan yang ditawarkan di dalam kampus. Kajian ini menggunakan kaedah borang kaji selidik sebagai kaedah untuk mengumpul data dengan melibatkan seramai 300 responden pelajar di kampus induk USM yang dipilih secara rawak. Analisis statistik deskriptif digunakan untuk mendapatkan nilai kekerapan dan peratusan. Hasil kajian menunjukkan bahawa pelbagai maklum balas daripada para responden tentang perkhidmatan kemudahan kesihatan yang disediakan di dalam kampus. Kajian ini dirujuk penting kepada pihak universiti sebagai bukti sama ada kemudahan perkhidmatan kesihatan yang ditawarkan di dalam kampus dapat diakses dengan baik mahupun sebaliknya. Kajian ini juga dapat memberi panduan dan cadangan kepada pihak universiti untuk menambah baik mutu perkhidmatan dan kemudahan kesihatan yang sedia ada khususnya kepada pelajar.
\end{abstract}

Kata kunci: tahap kepuasan, kemudahan kesihatan, pelajar, Universiti Sains Malaysia

\section{The Level of Students' Satisfaction towards Health Facility Services in the Main Campus of Universiti Sains Malaysia (USM)}

\begin{abstract}
Every university offers health facility services for the benefit of citizen on campus, especially students. Good healthcare facilities are indispensable and need to be emphasized by the university in order to ensure the sustainability of student health. Student satisfaction is an important factor in assessing the quality of healthcare facilities and services provided by the university. Therefore, this paper aims to examine the level of satisfaction of USM students towards the healthcare facilities and services offered on campus. This study uses the survey form method as a method to collect data by involving a total of 300 student respondents in the USM main campus which were randomly selected. Descriptive statistical analysis was used to obtain frequency and percentage values. The results of the study showed that various feedback from the respondents about the health facilities services provided on campus. This study is referred to as important to the university as an indicator whether the health service facilities offered on campus can be accessed well or otherwise. This study can also provide guidance
\end{abstract}


and suggestions to the university to improve the quality of existing health services and facilities, especially to students.

Keywords: level of satisfaction, health facilities, students, Universiti Sains Malaysia

\section{Pengenalan}

Akses kepada kesihatan juga dilihat meningkat seiring dengan kemajuan negara. World Health Organization (2018) menyatakan bahawa Universal Health Coverage membawa maksud perlindungan kesihatan sejagat, iaitu semua orang dapat menerima perkhidmatan kesihatan mengikut keperluan mereka termasuk inisiatif kesihatan yang direka untuk mempromosikan kesihatan yang lebih baik (seperti kempen anti-rokok), mencegah penyakit (seperti vaksin), memberi rawatan pemulihan, dan penjagaan paliatif (seperti penjagaan akhir hayat) yang cukup berkualiti dan berkesan. Pada masa yang sama, memastikan perkhidmatan tidak menyebabkan pengguna terdedah kepada masalah kewangan. Kesihatan adalah asas yang penting dalam kehidupan setiap manusia tidak terkecuali kepada para pelajar universiti. Menurut WHO, kesihatan ialah satu tahap atau keadaan yang mana setiap individu mempunyai kesejahteraan yang sempurna dari segi fizikal, mental dan sosial dan bukan semata-mata bebas daripada penyakit atau tidak berdaya (Callahan, 1973).

United Nation (2018) menggariskan dalam Matlamat Pembangunan Lestari (SDG) yang ke 3.8, iaitu untuk mengecapi perlindungan kesihatan sejagat, termasuk perlindungan risiko kewangan, akses kepada perkhidmatan penjagaan kesihatan yang penting dan akses kepada ubat-ubatan dan vaksin yang selamat, berkesan, berkualiti dan boleh diperoleh semua. Perkara ini menjadi garis panduan oleh kerajaan di seluruh dunia termasuk Malaysia. Menyambut baik cadangan UN, Kementerian Kesihatan Malaysia (KKM) telah berusaha untuk membolehkan rakyat Malaysia mendapatkan akses kesihatan dengan lebih baik. Oleh itu, pihak kementerian telah merangka dan melaksanakan Pelan Strategik KKM 2016-2020 bagi memastikan rakyat Malaysia dapat mengakses kemudahan dan rawatan kesihatan yang terbaik. Pelan ini diguna pakai dan menjadi garis panduan kesihatan oleh setiap negeri dalam Malaysia termasuklah Pulau Pinang.

Dalam memastikan setiap individu berada dalam keadaan sihat sewajarnya, Universiti Sains Malaysia (USM) tidak ketinggalan dalam memastikan kelestarian kesihatan setiap warganya. Pusat kesihatan universiti USM yang diberi nama "Pusat Sejahtera" ditubuhkan pada tahun 1969 dan menyediakan perkhidmatan perubatan dan pergigian kepada pelajar dan berkembang seterusnya kepada staf, tanggungan serta pesara USM. Pusat Sejahtera amat penting kepada warga USM. Hal ini demikian kerana pusat ini menjadi tumpuan utama bagi kebanyakan warganya apabila mengalami masalah kesihatan. Pusat Sejahtera membawa visi "mensejahterakan warga universiti dari aspek fizikal, mental, rohaniah dan sosial bagi memenuhi hasrat universiti ke arah kecemerlangan dan kelestarian" dan misi "memberi tumpuan yang komprehensif dan berterusan dalam aspek pencegahan, perawatan, pemulihan dan pengurusan sumber demi kesejahteraan warga universiti". Hal ini jelas membawa maksud bahawa Pusat Sejahtera mementingkan kesejahteraan warganya serta siap siaga memberi perkhidmatan kesihatan yang baik.

Namun, terdapat beberapa aduan daripada para pelajar yang timbul berkenaan dengan perkhidmatan yang ditawarkan oleh Pusat Sejahtera. Aduan-aduan ini dapat dikenal pasti di laman media sosial dan juga melalui penyampaian verbal daripada para pelajar. Hal ini secara tidak langsung dapat memberi gambaran mengenai tahap kepuasan para pelajar terhadap perkhidmatan Pusat Sejahtera. Adalah penting untuk menilai tahap kepuasan para pelajar berkenaan perkhidmatan kemudahan kesihatan. Hal ini penting untuk menilai kualiti perkhidmatan kemudahan kesihatan tersebut sama ada berada dalam keadaan yang baik ataupun sebaliknya. Oleh itu, kajian ini bertujuan untuk mengkaji tahap kepuasan pelajar terhadap perkhidmatan yang ditawarkan oleh Pusat Sejahtera dari aspek akses ketersediaan (availability) dan akses kesesuaian (appropriateness). 


\section{Kajian literatur}

Menurut Schroeder et al. (2012), penjagaan kesihatan yang lestari mempunyai tiga faktor, iaitu perkhidmatan kesihatan yang berkualiti, menyeimbangkan ekonomi secara bertanggungjawab dan meminimumkan impak persekitaran untuk generasi masa hadapan. Perkhidmatan kesihatan yang lestari adalah perkhidmatan kesihatan yang berkualiti yang mana kebajikan pesakit dijaga dengan baik dan berterusan. Kesemua aspek diambil kira bagi memastikan pesakit mendapat perkhidmatan kesihatan yang terbaik. Perkhidmatan kesihatan ini termasuklah dari segi fizikal, mental dan spiritual pesakit. Aspek fizikal adalah aspek luaran pesakit seperti kesakitan yang dialami pesakit semasa menerima rawatan. Aspek mental adalah berkaitan dengan emosi dan perasaan pesakit semasa menerima rawatan. Manakala aspek spiritual pula bermaksud mengambil kira keadaan rohani pesakit. Bagi memastikan pesakit menerima rawatan yang lestari, pekerja perkhidmatan kesihatan perlu memastikan pesakit berpuas hati dengan perkhidmatan kesihatan yang diterima dari segi fizikal, mental dan rohani.

Selain itu, Stahl (2003) menyatakan terdapat empat ciri akses kemudahan kesihatan, iaitu ketersediaan (availability), kemampuan (affordability), kesesuaian (appropriateness) dan penerimaan (acceptability) pesakit terhadap penawaran kesihatan adalah penting untuk melihat sejauh mana pesakit dapat menerima rawatan seterusnya berpuas hati dengan layanan yang diberikan oleh pusat rawatan kesihatan. Hal ini bagi memastikan hubungan dua hala antara pesakit dan pusat rawatan lebih telus. Jika salah satu ciri akses ini tidak dapat dipenuhi, maka akan berlaku masalah-masalah ketidakpuasan hati pesakit terhadap layanan yang diberi oleh pusat rawatan. Dalam konteks kajian ini, ciri akses ketersediaan adalah kewujudan Pusat Sejahtera yang terletak dalam USM sebagai pusat untuk menjaga kebajikan pelajar dalam mendapatkan rawatan kesihatan. Namun, akses ketersediaan ini adalah terhad kerana Pusat Sejahtera tidak beroperasi sepenuh masa dan pelajar perlu ke klinik panel yang terletak di luar kampus untuk mendapatkan rawatan. Dari aspek kemampuan pula, pelajar telah membayar yuran kebajikan semasa mendaftar semester, maka sepatutnya masalah kewangan untuk mendapatkan rawatan kesihatan tidak berlaku kepada pelajar dan pengangkutan di dalam kampus seperti bas juga disediakan. Permasalahan hanya akan timbul jika pelajar mengalami masalah kesihatan pada waktu di luar operasi Pusat Sejahtera. Aspek kesesuaian pula boleh dilihat apabila pelajar berasa tidak selesa atau sesuai dengan layanan yang diterima daripada staf Pusat Sejahtera. Jika timbul rasa tidak puas hati pelajar terhadap kemudahan kesihatan yang digunakan, maka akses kepada kemudahan kesihatan ini akan dilihat sebagai satu kepincangan. Hizlinda et al. (2012) menyatakan bahawa kepuasan pesakit memainkan peranan yang penting dalam memastikan penggunaan perkhidmatan jagaan kesihatan, rawatan berterusan dan kepatuhan terhadap rawatan kesihatan. Kepuasan pesakit juga menjurus kepada kemudahan bagi pesakit tersebut dalam mendapatkan rawatan. Jika pengguna tidak berpuas hati dengan rawatan yang diterima, perkara ini akan mengakibatkan kesan kepatuhan pengguna untuk mendapatkan rawatan pada masa akan dating. Terakhir sekali adalah aspek penerimaan (acceptability) yang merujuk kepada penerimaan pelajar tentang kewujudan kemudahan kesihatan. Penerimaan ini boleh dilihat apabila pelajar bersetuju untuk menggunakan perkhidmatan kesihatan yang disediakan oleh pihak universiti.

Di samping itu, akses pula mempunyai empat dimensi, iaitu ketersediaan, aksesibiliti geografi, kemampuan dan kebolehterimaan (O'Donnell, 2007). Akses kepada penjagaan kesihatan boleh ditakrifkan dalam pelbagai cara. Dalam erti kata yang paling mudah, ia merujuk kepada ketersediaan geografi. Takrifan yang lebih luas mengenal pasti empat dimensi akses, iaitu ketersediaan, kebolehaksesan, kemampuan, dan kebolehterimaan. Sesetengah pelopor menyatakan bahawa akses adalah peluang pesakit untuk mendapatkan atau menggunakan perkhidmatan rawatan kesihatan manakala sesetengah pelopor teori lain tidak membezakan antara akses dan penggunaan. Levesque (2013) menyatakan bahawa akses ditakrifkan sebagai peluang untuk mencapai dan mendapatkan perkhidmatan penjagaan kesihatan. Akses dilihat sebagai hasil daripada antara ciri seseorang, isi rumah, persekitaran sosial dan fizikal dengan ciri-ciri kesihatan, organisasi dan pembekal untuk mendapatkan perkhidmatan penjagaan kesihatan yang sesuai dengan keadaan. Oleh itu, akses dilihat sebagai kemungkinan untuk mengenal pasti keperluan penjagaan kesihatan, untuk mendapatkan penjagaan perkhidmatan kesihatan, untuk mencapai sumber penjagaan kesihatan, untuk mendapatkan atau menggunakan perkhidmatan penjagaan kesihatan, dan benar-benar ditawarkan perkhidmatan 
sesuai dengan keperluan penjagaan kesihatan. Oleh itu, akses kesihatan dikatakan sebagai hubungan dua hala di antara individu atau kumpulan dengan organisasi yang menawarkan perkhidmatan kesihatan.

Tambahan pula, Harold dan Victor (1996) menekankan bahawa walaupun terdapat pengguna yang berpendapatan rendah, mereka sanggup membayar lebih untuk mendapatkan penjagaan kesihatan yang baik sekiranya bayaran perkhidmatan diberikan adalah setimpal. Namun, apabila harga meningkat tanpa penambahbaikan dalam perkhidmatan, pengguna akan mempunyai masalah kepercayaan terhadap sesuatu perkhidmatan. Hal ini boleh dikaitkan dengan situasi pelajar yang mana jika pelajar tidak berpuas hati dengan perkhidmatan kesihatan yang disediakan oleh Pusat Sejahtera, pelajar mungkin tidak akan menggunakan Pusat Sejahtera sebagai kemudahan kesihatan yang utama dan sanggup membayar lebih untuk mendapatkan kemudahan kesihatan di luar kampus walaupun telah membayar yuran kesihatan untuk setiap semester. Menurut Yang et al. (2006), penjagaan kesihatan yang tidak adil telah lama diakui sebagai satu masalah dalam arena kesihatan. Hal ini akan menyebabkan pengguna akan mencari fasiliti kesihatan yang lebih baik di kawasan lain.

\section{Metod Kajian}

Kaedah kuantitatif iaitu pengedaran borang soal selidik digunakan dalam menjalankan kajian ini. 300 responden dipilih secara persampelan bertujuan di mana hanya pelajar Pusat Pengajian Ilmu Kemanusiaan sahaja terlibat dalam kajian ini dan responden dipilih bagi responden yang pernah mendapatkan perkhidmatan kesihatan di Pusat Sejahtera. Justifikasi hanya pelajar Pusat Pengajian Ilmu Kemanusiaan yang dipilih adalah pengkaji hanya ingin membuat tinjauan awal dan pengkaji akan meneruskan lagi kajian ini dengan membuat perbandingan sampel dari pusat pengajian yang lain kelak. Lokasi kajian dijalankan di dalam kampus induk USM sahaja yang terletak di daerah Timur Laut, Pulau Pinang. Dapatan data dianalisis dengan menggunakan perisian Statistical Packages for the Social Science (SPSS) versi 26.0. Analisis statistik deskriptif digunakan dalam kajian ini untuk mendapatkan nilai peratusan. Borang soal selidik dalam kajian ini terbahagi kepada 4 bahagian, iaitu profil responden, kemudahan kesihatan utama, interaksi pesakit dengan doktor, perkhidmatan yang ditawarkan oleh Pusat Sejahtera, dan kepuasan terhadap kemudahan Pusat Sejahtera. Kaji selidik menggunakan 2 tahap iaitu (TS= tidak setuju, $S=$ setuju). Sebelum kajian sebenar dijalankan, ujian rintis telah dijalankan terlebih dahulu terhadap 30 responden pelajar induk USM. Hasil ujian rintis tersebut menunjukkan nilai kebolehpercayaan Cronbach Alpha bagi kaji selidik adalah sebanyak 0.947 .

\section{Hasil Kajian}

\section{Profil responden}

Jadual 1 menunjukkan profil responden. Bagi kategori jantina responden yang terlibat dalam kajian ini, sebanyak $41.7 \%$ responden adalah lelaki dan $58.3 \%$ responden lagi adalah wanita. Kategori umur pula menunjukkan sebanyak $82.7 \%$ responden terdiri daripada umur 18 hingga 30 tahun, 9.3\% responden berumur 31 hingga 40 tahun dan selebihnya $8.0 \%$ responden berumur 41 tahun dan ke atas. Bagi kategori bangsa, sebanyak $77.3 \%$ responden terdiri daripada bangsa Melayu, $11.0 \%$ responden berbangsa Cina, $6.0 \%$ responden berbangsa India, dan 5.7\% responden berbangsa lain-lain.

Jadual 1: Profil responden

\begin{tabular}{lcc}
\hline Kategori & N=300 & Peratusan (\%) \\
\hline Jantina & & \\
$\quad$ Lelaki & 125 & 41.7 \\
$\quad$ Wanita & 175 & 58.3 \\
Umur & & \\
$\quad$ 18-30 Tahun & 248 & 82.7 \\
\hline
\end{tabular}


DOI: https://doi.org/10.47405/mjssh.v6i2.670

\begin{tabular}{lcc}
\hline 31-40 Tahun & 28 & 9.3 \\
41 Tahun Dan Keatas & 24 & 8.0 \\
Bangsa & & \\
Melayu & 232 & 77.3 \\
Cina & 33 & 11.0 \\
India & 18 & 6.0 \\
Lain-lain & 17 & 5.7 \\
\hline
\end{tabular}

\section{Kemudahan kesihatan utama}

Jadual 2 menunjukkan bahawa lebih separuh daripada responden, iaitu seramai 183 responden (61\%) menjadikan pusat sejahtera sebagai kemudahan kesihatan utama mereka. Hal ini menunjukkan Pusat Sejahtera penting kepada responden untuk mendapatkan perkhidmatan kesihatan.

Jadual 2: Jadual silang kemudahan kesihatan utama

\begin{tabular}{ll}
\hline Fasiliti Kesihatan & Peratus (\%) \\
\hline Pusat Sejahtera & 61 \\
Selain Pusat Sejahtera & 39 \\
\hline Jumlah & 100 \\
\hline
\end{tabular}

Jadual 3 menunjukkan data dari jadual silang (crosstabulation) mendapati sebanyak $26(\%)$ responden lelaki memilih Pusat Sejahtera sebagai kemudahan kesihatan utama mereka dan $16(\%)$ responden lelaki lagi tidak meletakkan Pusat Sejahtera sebagai kemudahan kesihatan utama mereka. Jadual silang bagi responden wanita pula menunjukkan sebanyak $35(\%)$ responden perempuan memilih pusat sejahtera kemudahan kesihatan utama mereka, dan $23(\%)$ responden perempuan lagi tidak meletakkan Pusat Sejahtera sebagai kemudahan kesihatan utama mereka. Daripada temu bual ringkas yang dijalankan bersama responden, mereka memilih untuk mendapatkan rawatan kesihatan dari Hospital Besar Pulau Pinang, klinik panel, hospital swasta dan klinik swasta. Pilihan ini dibuat kerana responden menyatakan bahawa mereka mampu untuk mendapatkan rawatan kesihatan yang lebih efisien, baik dan berpuas hati dengan perkhidmatan yang ditawarkan.

Jadual 3: Jadual silang fasiliti kesihatan utama mengikut jantina

\begin{tabular}{llll}
\hline Jantina & Pusat Sejahtera & $\begin{array}{l}\text { Bukan Pusat } \\
\text { Sejahtera }\end{array}$ & Total \\
\hline Lelaki & 77 & 48 & 125 \\
Perempuan & 106 & 69 & 175 \\
\hline Jumlah & 183 & 117 & 300 \\
\hline
\end{tabular}

Hal ini selari dengan teori oleh Harold dan Victor (1996) yang menekankan bahawa pengguna walaupun mereka yang berpendapatan rendah, mereka sanggup membayar lebih untuk penjagaan kesihatan yang lebih baik sekiranya bayaran perkhidmatan diberikan adalah setimpal. Tetapi apabila harga meningkat tanpa penambahbaikan dalam perkhidmatan, pengguna akan mempunyai masalah kepercayaan terhadap sesuatu perkhidmatan ini dilihat bersesuaian dengan situasi ini apabila 39 peratus pelajar tidak memilih Pusat Sejahtera sebagai fasiliti kesihatan utama mereka dan memilih untuk mendapatkan rawatan kesihatan berbayar dan terletak jauh di luar kampus. Walaupun harga perkhidmatan kesihatan yang ditawarkan oleh Pusat Sejahtera kepada pelajar adalah rendah, namun segelintir pelajar mementingkan kualiti perkhidmatan yang diberi. Dapatan ini menunjukkan Pusat Sejahtera masih menjadi pilihan utama kepada pelajar, namun bukan dalam jumlah majoriti yang besar. Hal ini harus diambil berat kerana jumlah pelajar yang tidak memilih Pusat Sejahtera sebagai fasiliti kesihatan yang utama adalah agak tinggi. Jumlah pelajar untuk tidak memilih fasiliti ini sebagai fasiliti kesihatan yang utama mungkin akan meningkat jika servis perkhidmatan tidak diperbaiki pada masa akan datang. 


\section{Interaksi doktor dengan pesakit}

Jadual 4 menunjukkan interaksi responden dengan doktor yang merawat mereka. Sebanyak 93.3\% responden bersetuju dan $6.7 \%$ responden tidak bersetuju bahawa mereka mendapat layanan yang baik daripada doktor di Pusat Sejahtera. Sebanyak 92.0\% responden bersetuju dan 8.0\% tidak bersetuju bahawa doktor di Pusat Sejahtera memahami privasi mereka sebagai pesakit. Bagi kenyataan berikutnya, iaitu "doktor memberi saya peluang untuk bercakap tentang penyakit saya" dipersetujui seramai $92.3 \%$ responden dan selebihnya $7.7 \%$ responden tidak bersetuju. Seramai $89.7 \%$ responden bersetuju dan $10.3 \%$ responden lagi tidak bersetuju bahawa masalah penyakit mereka didengar dengan baik oleh doktor. Sebanyak $89.3 \%$ responden bersetuju dan dan $10.3 \%$ responden lagi tidak bersetuju bahawa doktor di Pusat Sejahtera memberikan masa rawatan yang cukup kepada mereka. Sebanyak $87.3 \%$ responden bersetuju dan $12.7 \%$ responden lagi tidak bersetuju bahawa mereka diberikan maklumat tentang penyakit dialami. Sebanyak $83.7 \%$ responden bersetuju dan $16.3 \%$ responden lagi tidak bersetuju bahawa doktor menjelaskan tentang dos ubatan mereka. Sebanyak 83.3\% responden bersetuju bahawa doktor menjelaskan kepada mereka tentang kesan sampingan ubatan dan selebihnya 16.7\% responden tidak bersetuju. Sebanyak $87.3 \%$ responden bersetuju bahawa mereka dinasihatkan doktor untuk mendapatkan rawatan lanjut dan $12.7 \%$ responden lagi tidak bersetuju. Sebanyak $90.0 \%$ responden bersetuju dan $10.0 \%$ responden lagi tidak bersetuju bahawa doktor mendapatkan persetujuan mereka untuk menjalankan rawatan terhadap mereka. Akhir sekali, sebanyak 92.3\% responden bersetuju dan $7.7 \%$ responden lagi tidak bersetuju bahawa doktor di Pusat Sejahtera membuatkan mereka berasa selesa semasa menjalankan rawatan terhadap mereka.

Jadual 4: Interaksi doktor dengan pesakit

\begin{tabular}{lll}
\hline Interaksi Doktor Dengan Pesakit & $\begin{array}{l}\text { Tidak } \\
\text { Setuju } \\
(\boldsymbol{\%})\end{array}$ & $\begin{array}{l}\text { Setuju } \\
(\boldsymbol{\%})\end{array}$ \\
\hline Saya dilayan dengan baik oleh doktor & 6.7 & 93.3 \\
Doktor memahami privasi saya & 8.0 & 92.0 \\
Doktor memberi saya peluang bercakap tentang penyakit saya & 7.7 & 92.3 \\
Masalah penyakit saya didengar dengan baik oleh doktor & 10.3 & 89.7 \\
Doktor memberikan masa rawatan yang cukup kepada saya & 10.7 & 89.3 \\
Saya diberikan maklumat mengenai penyakit saya & 12.7 & 87.3 \\
Doktor menjelaskan kepada saya tentang penyakit saya & 13.7 & 86.3 \\
Doktor menjelaskan kepada saya tentang dos ubatan saya & 16.3 & 83.7 \\
Doktor menjelaskan kepada saya tentang kesan sampingan ubatan saya & 16.7 & 83.3 \\
Doktor menasihati saya untuk membuat rawatan lanjut & 12.7 & 87.3 \\
Doktor mendapatkan persetujuan saya untuk menjalankan rawatan & 10.0 & 90.0 \\
Doktor membuat saya selesa semasa menjalankan rawatan & 7.7 & 92.3 \\
\hline
\end{tabular}

Peratusan yang positif ini menunjukkan bahawa kebanyakan responden berpuas hati dengan perkhidmatan kesihatan yang diberikan oleh doktor di Pusat Sejahtera kepada mereka. Peratusan yang kecil ini merupakan satu punca masalah kepada ketidaklestarian perkhidmatan yang ditawarkan oleh Pusat Sejahtera kepada pelajar kerana hal ini menjadi punca Pusat Sejahtera mendapat maklum balas yang negatif. Teori yang diketengahkan oleh Hizlinda et al. (2012) menyatakan bahawa kepuasan pesakit memainkan peranan yang penting dalam memastikan penggunaan perkhidmatan kesihatan, rawatan berterusan dan kepatuhan terhadap rawatan kesihatan ini boleh dikaitkan dengan rawatan kesihatan yang diberikan oleh doktor kepada responden dan seterusnya menyebabkan responden patuh untuk mendapatkan rawatan pada masa hadapan. Dapatan ini menunjukkan bahawa hubungan atau interaksi pelajar dengan doktor di Pusat Sejahtera adalah baik. Namun, kadar penerimaan (acceptance) pelajar dengan perkhidmatan yang diterima daripada doktor adalah memuaskan. Walau bagaimanapun, keadaan ini mungkin akan berubah jika tiada penambahbaikan yang berlaku dalam perkhidmatan yang ditawarkan. 


\section{Perkhidmatan di PusatSejahtera}

Jadual 5 menunjukkan perkhidmatan yang ditawarkan oleh Pusat Sejahtera kepada responden. Sebanyak $86.7 \%$ responden bersetuju bahawa mereka mudah untuk mencari kaunter pertanyaan di Pusat Sejahtera dan sebanyak $13.3 \%$ responden lagi tidak bersetuju. Sebanyak $86.0 \%$ peratus responden bersetuju bahawa tiket giliran mudah diambil dan $14.0 \%$ peratus lagi tidak bersetuju. Sebanyak $70.7 \%$ responden bersetuju bahawa mereka hanya perlu menunggu seketika sebelum mendapatkan rawatan dan $29.3 \%$ responden lagi tidak bersetuju. Sebanyak $89.3 \%$ responden bersetuju bahawa Pusat Sejahtera mempunyai ruangan menunggu yang selesa manakala $10.7 \%$ responden lagi tidak bersetuju. Sebanyak $82.0 \%$ responden bersetuju bahawa Pusat Sejahtera menyediakan ruang tempat duduk yang banyak dan selesa manakala $18.0 \%$ responden lagi tidak bersetuju. Sebanyak 68.3\% responden menyatakan bahawa air minuman disediakan di Pusat Sejahtera manakala 16.3\% responden lagi tidak. Seramai $83.7 \%$ responden bersetuju bahawa staf di Pusat Sejahtera menghormati mereka manakala $16.3 \%$ responden lagi tidak bersetuju. Sebanyak $86 \%$ responden bersetuju bahawa staf di Pusat Sejahtera melayan mereka dengan adil manakala 14\% responden lagi tidak bersetuju. Sebanyak 83.3\% responden bersetuju bahawa staf di Pusat Sejahtera bersikap positif terhadap mereka manakala $16.7 \%$ responden lagi tidak bersetuju. Sebanyak $79.0 \%$ responden bersetuju bahawa Pusat Sejahtera tidak terlalu sesak kerana staf yang mencukupi manakala $21.0 \%$ responden lagi tidak bersetuju. Akhir sekali, sebanyak 75.7\% responden bersetuju tempat parkir kenderaan banyak di Pusat Sejahtera manakala $24.3 \%$ responden lagi tidak bersetuju.

Jadual 5: Servis di Pusat Sejahtera

\begin{tabular}{llc}
\hline Jadual 5: Servis Di Pusat Sejahtera & $\begin{array}{l}\text { Tidak } \\
\text { Setuju }\end{array}$ & Setuju \\
\hline Kaunter pertanyaan di di Pusat Sejahtera senang dicari & 13.3 & 86.7 \\
Tiket giliran rawatan kesihatan senang diambil & 14.0 & 86.0 \\
Saya hanya menunggu seketika sebelum mendapat rawatan & 29.3 & 70.7 \\
Tempat menunggu sangat selesa & 10.7 & 89.3 \\
Ruang tempat duduk yang banyak dan selesa & 18.0 & 82.0 \\
Air minuman disediakan & 31.7 & 68.3 \\
Pekerja di Pusat Sejahtera menghormati pesakit dan pelanggan & 16.3 & 83.7 \\
Pekerja di Pusat Sejahtera melayan pesakit dan pelanggan dengan adil dan & 14.0 & 86.0 \\
saksama & & \\
Jururawat bersikap positif kepada pesakit & 16.7 & 83.3 \\
Pusat Sejahtera tidak terlalu sesak kerana kecukupan pekerja & 21.0 & 79.0 \\
Tempat parkir banyak disediakan untuk pesakit dan pelanggan & 24.3 & 75.7 \\
\hline
\end{tabular}

Walaupun peratusan responden tidak bersetuju dengan kenyataan yang diberikan tidak terlalu tinggi namun angka tersebut bukanlah sebuah angka yang rendah. Hal ini demikian kerana sesetengah responden sudah menetapkan fikiran mereka bahawa sesetengah staf yang mereka telah kenalpasti mempunyai sikap yang tidak baik terhadap pesakit atau mereka. Perkara ini boleh membawa keburukan kepada kelestarian perkhidmatan yang ditawarkan oleh Pusat Sejahtera kepada pelajar dan mampu menjejaskan Visi dan Misi yang didukung oleh Pusat Sejahtera.

Rajah 1 merupakan contoh perbualan para pelajar tentang perkhidmatan Pusat Sejahtera yang diperoleh daripada laman sesawang Facebook. Dapat dilihat melalui perbualan tersebut, pelajar-pelajar telah mendapatkan rawatan kesihatan di Pusat Sejahtera dan meluahkan rasa tidak puas hati terhadap perkhidmatan yang ditawarkan. Terdapat beberapa lagi ulasan yang sama dapat dibaca dan dilihat di halaman tersebut. Terdapat masalah perkhidmatan yang dilontarkan di media sosial, terdapat juga masalah yang didengar daripada mulut ke mulut. Pelbagai bentuk cerita negatif dapat didengar daripada para pelajar tentang perkhidmatan yang mereka peroleh di Pusat Sejahtera. Namun, terdapat juga ulasan yang positif. Perkara ini harus diselami dan diteliti kerana Pusat Sejahtera merupakan sebuah kemudahan yang disediakan oleh pihak universiti untuk memastikan kelestarian, kesejahteraan dan kebajikan pelajar. Akan tetapi, para pelajar juga dikenakan yuran kebajikan untuk mendapatkan 
perkhidmatan kesihatan ini. Oleh itu, pelajar berhak untuk mendapatkan perkhidmatan yang terbaik dari Pusat Sejahtera.

Rajah 1: Perbualan pelajar di ruangan ulasan

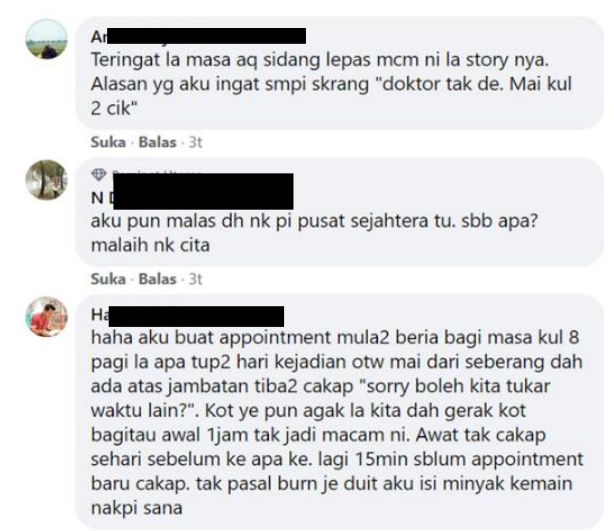

Sumber: Laman Facebook USM Life Confession.

Berikut merupakan satu lagi contoh aduan pelajar tentang masalah mereka dalam mendapatkan rawatan di Pusat Sejahtera.

\section{Rajah 2: Aduan pelajar di Facebook USM Life Confession}

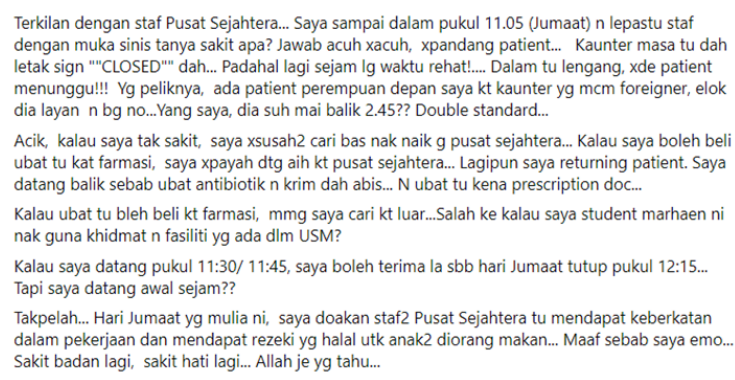

Sumber: Laman Facebook USM Life Confession.

Luahan hati pelajar tersebut telah mendapat sambutan daripada beberapa pelajar lain yang pernah mengalami nasib yang sama. Perkara ini dikatakan acap kali berlaku terutama pada hari Jumaat. Pada hari Jumaat, tempoh masa rawatan adalah terhad dan Pusat Sejahtera akan menutup perkhidmatannya pada hari minggu. Kaunter utama dikatakan menutup perkhidmatan mereka terlalu awal dari tempoh masa rawatan dan hanya akan dibuka lewat dari waktu yang sepatutnya. Namun, waktu rawatan yang tinggal hanya sedikit kerana tempoh waktu rawatan hampir tamat. Staf yang menjalankan tugas juga dikatakan tidak mesra pelajar dan menyebabkan pelajar tidak berpuas hati dengan perkhidmatan yang diberikan. Staf terlalu garang, staf tidak memberi layanan dengan baik juga menjadi topik luahan para pelajar. Perasaan kurang senang dan menimbulkan rasa tidak puas hati ini perlu dibendung agar tidak merosakkan nama baik pihak universiti kerana ia mampu menjadi bukti bahawa kemudahan yang disediakan oleh pihak universiti tidak lestari dan tidak menjaga kesejahteraan pelajarnya.

Teori kepada akses kepada perkhidmatan kesihatan seperti ketersediaan dan kesesuaian yang diperkatakan oleh O'Donnell (2007) dan Stahl (2003) dapat dikaitkan apabila setiap perkhidmatan yang ditawarkan oleh fasiliti kesihatan menjadi isu atau perkara yang diambil berat oleh responden semasa mereka mendapatkan perkhidmatan kesihatan di Pusat Sejahtera. Setiap perkhidmatan menjadi penentu kepada kelestarian perkhidmatan kesihatan yang disediakan oleh Pusat Sejahtera untuk penggunanya. Apabila sesuatu isu dibangkitkan dan menjadikan pelajar tidak berpuas hati dengan perkhidmatan yang diterima, maka akses kesihatan yang ditawarkan oleh Pusat Sejahtera kepada pelajar dianggap tidak lestari. Daripada jadual dapat dilihat peratusan untuk pernyataan "air minuman disediakan", "saya hanya menunggu seketika sebelum mendapat rawatan" dan "tempat parkir banyak 
disediakan untuk pesakit" adalah lebih 20\% hingga 30\%. Hal ini menunjukkan responden tidak berpuas hati dengan perkhidmatan yang ditawarkan. Masalah ini perlu diselesaikan bagi mengelakkan penurunan tahap kepuasan responden pada masa hadapan. Ciri akses ketersediaan (availability) dan kesesuaian (appropriateness) masih perlu diperbaiki supaya Pusat Sejahtera dapat menawarkan perkhidmatan kesihatan yang lebih lestari pada masa hadapan.

\section{Tahap kepuasan terhadap kemudahan}

Jadual 6 menunjukkan jumlah bintang yang melambangkan tahap kepuasan responden terhadap keseluruhan perkhidmatan dan penampilan yang ditunjukkan oleh Pusat Sejahtera. Secara keseluruhannya, sebanyak 24.3\% responden memberi lima bintang untuk kebersihan Pusat Sejahtera, diikuti $38.0 \%$ responden memberi empat bintang, 34.7\% responden memberi tiga bintang, $2.7 \%$ responden memberi dua bintang dan $0.3 \%$ responden memberi satu bintang. Bagi pemarkahan untuk kebersihan tandas Pusat Sejahtera, sebanyak 21.0\% responden memberi lima bintang, 39.3\% responden memberi empat bintang, 32.7\% responden memberi tiga bintang, 6.0\% responden memberi dua bintang dan $1.0 \%$ responden memberi satu bintang. Bagi kategori kebersihan katil pesakit di Pusat Sejahtera, sebanyak $22.3 \%$ responden memberi lima bintang, $40.3 \%$ responden memberi empat bintang, 33.7\% responden memberi tiga bintang, 3.3\% responden memberi dua bintang dan $0.3 \%$ responden sahaja yang memberi satu bintang. Secara keseluruhannya, sebanyak $23.0 \%$ responden memberi lima bintang untuk kenyataan "saya sangat berpuas hati dengan Pusat Sejahtera", peratusan ini tidak tinggi malah agak rendah dan menunjukkan responden merasakan kekurangan dalam mendapatkan perkhidmatan kesihatan di sini. Kekurangan yang dirasakan oleh para responden boleh menjadi penentu untuk mereka mendapatkan rawatan kesihatan di Pusat Sejahtera.

Jadual 6: Pusat Sejahtera

\begin{tabular}{|c|c|c|c|c|c|}
\hline Pusat Sejahtera & 1 & 2 & 3 & 4 & 5 \\
\hline Pusat Sejahtera ini sangat bersih & 0.3 & 2.7 & 34.7 & 38 & 24.3 \\
\hline Tandas Pusat Sejahtera sangat bersih & 1.0 & 6.0 & 32.7 & 39.3 & 21.0 . \\
\hline Katil pesakit sangat bersih & 0.3 & 3.3 & 33.7 & 40.3 & 22.3 \\
\hline Saya sangat berpuas hati dengan Pusat Sejahtera & 0.7 & 3.7 & 35 & 37.7 & 23.0 \\
\hline $\begin{array}{l}\text { Dalam skala } 1-5 \text {, beri markah untuk doktor di Pusat } \\
\text { Sejahtera }\end{array}$ & 0.7 & 2.7 & 27.3 & 46.3 & 23.0 \\
\hline $\begin{array}{l}\text { Dalam skala 1-5, beri markah untuk jururawat di Pusat } \\
\text { Sejahtera }\end{array}$ & 0.7 & 3.7 & 33.3 & 39.3 & 23.0 \\
\hline $\begin{array}{l}\text { Dalam skala 1-5, beri markah untuk pekerja di Pusat } \\
\text { Sejahtera }\end{array}$ & 0.3 & 3.3 & 35.3 & 35.7 & 25.3 \\
\hline $\begin{array}{l}\text { Dalam skala 1-5, beri markah untuk parkir kereta di } \\
\text { Pusat Sejahtera }\end{array}$ & 2.0 & 8.0 & 31.3 & 37 & 21.7 \\
\hline $\begin{array}{l}\text { Dalam skala 1-5, beri markah untuk keseluruhan Pusat } \\
\text { Sejahtera }\end{array}$ & 0.3 & 2.3 & 30.3 & 42.0 & 25.0 \\
\hline
\end{tabular}

Dapat dilihat hanya empat bintang markah tertinggi yang paling banyak diberikan oleh responden terhadap kepuasan mereka dalam menggunakan perkhidmatan kesihatan di Pusat Sejahtera. Namun peratusan empat bintang tidaklah mencapai 50\% responden dan peratusan tertinggi sebanyak $46.3 \%$ untuk empat bintang adalah markah untuk kepuasan hati responden terhadap doktor di Pusat Sejahtera manakala kemudahan di Pusat Sejahtera secara keseluruhannya hanya mendapat empat bintang, iaitu 42.0\% daripada keseluruhan responden. Hal ini menunjukkan bahawa responden tidak sepenuhnya berpuas hati dengan perkhidmatan kesihatan yang diberikan oleh Pusat Sejahtera. Dapat disimpulkan di sini bahawa perkhidmatan kesihatan yang ditawarkan oleh Pusat Sejahtera adalah tidak lestari secara sepenuhnya dan perlu diperbaiki demi meningkatkan kualiti perkhidmatan pada masa hadapan. 


\section{Kesimpulan}

Secara rumusannya, kajian ini mendapati bahawa terdapat kepincangan dalam perkhidmatan yang disediakan oleh Pusat Sejahtera yang menyumbang kepada isu-isu ketidakpuashatian pelajar terhadap perkhidmatan yang diperolehi. Hal ini menjadikan kurang separuh daripada pelajar di USM tidak lagi mendapatkan perkhidmatan kesihatan di Pusat Sejahtera namun mengambil inisiatif lain seperti mendapatkan perkhidmatan kesihatan di klinik luar walaupun pelajar telah membayar yuran kesihatan semasa mendaftar semester. Perkara ini harus diambil berat oleh semua pihak terutama pihak universiti kerana masalah ini boleh dikatakan masalah dalaman yang berlaku di dalam universiti. Cadangan yang ingin diutarakan adalah supaya pihak pengurusan Pusat Sejahtera, dan bahagian hal ehwal pelajar dalam universiti dapat memperbaiki dan menambah baik perkhidmatan yang ditawarkan kepada pelajar supaya pelajar dapat menikmati kemudahan kesihatan yang lebih baik dan lestari pada masa hadapan. Hal ini bukan sahaja memberikan keselesaan kepada pelajar malah dapat meningkatkan kelestarian kesihatan di dalam kampus serta pihak Pusat Sejahtera dapat membawa Visi dan Misi mereka dengan lebih baik.

\section{Penghargaan}

Pengkaji ingin merakamkan penghargaan kepada Universiti Sains Malaysia dan Kementerian Pendidikan Malaysia yang telah membiayai kajian ini melalui geran penyelidikan fundamental FRGS (203/PHUMANITI/6711647) yang bertajuk A Socio-Ecological Approach to Examining Health Behaviour and Health Equity in Urban Areas of Malaysia.

\section{Rujukan}

Callahan, D. (1973). The WHO definition of 'Health'. The Hastings Center Studies, 1(3), 77-87.

Harold Alderman, Victor Lavy. (1996). Household responses to public health services: cost and quality tradeoffs. The World Bank Research Observer, 11(1), 3-22.

Hizlinda, T., Teoh, S. Y., Siti Nurbaiyah, K. E., Azrina, A. S., Hafizuddin, M. M. T., \& Chang, L. H. (2012). A Cross-Sectional Study on Patient Satisfaction with Universiti Kebangsaan Malaysia Medical Centre (UKMMC) Primary Care Clinic. Med and Health, 7(1), 12-23.

Laman Web Rasmi Kementerian Kesihatan Malaysia. Diakses dari https://www.moh.gov.my/index.php/pages/view/1917?mid=613

Levesque, J. F., Harris, M. F., \& Russell, G. (2013). Patient-centred access to health care: conceptualising access at the interface of health systems and populations. International journal for equity in health, 12(1), 18.

O'Donnell, O. (2007). Access to health care in developing countries: breaking down demand side barriers. Cadernos de saude publica, 23, 2820-2834.

Schroeder, K., Thompson, T., Frith, K., \& Pencheon, D. (2012). Sustainable healthcare. John Wiley \& Sons.

Stahl, M. J. (Ed.). (2003). Encyclopedia of health care management. Sage Publications.

World Health Organization. (2018). Annual report on monitoring progress on UHC and the healthrelated SDGs (No. SEA/RC71/12). World Health Organization. Regional Office for South-East Asia. 